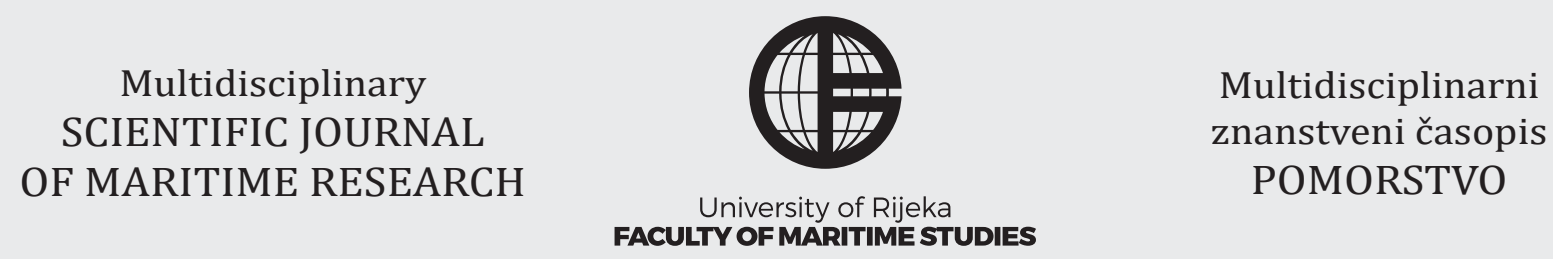

\title{
Attitudes on Introduction of Electric Ships in the Coastal Maritime Traffic of the Republic of Croatia
}

\author{
Antonija Mišura ${ }^{1}$, Tatjana Stanivuk ${ }^{1}$, Dragan Čišić ${ }^{2}$ \\ ${ }^{1}$ University of Split, Faculty of Maritime Studies, Split, Croatia, e-mail: amisura@pfst.hr; tatjana.stanivuk@pfst.hr \\ ${ }^{2}$ University of Rijeka, Faculty of Maritime Studies Rijeka, Rijeka, Croatia, e-mail: dragan@pfri.hr
}

\begin{abstract}
This paper discusses the data collected through a survey which examined attitudes of participants in the costal maritime traffic of the Republic of Croatia on the introduction of electric ships in the system. Croatia has one of the most indented coastlines in Europe and the world, and $2.92 \%$ of its total population lives just on the islands. An important factor for the life of the island's population and sustainable development of the island is certainly public traffic in the coastal maritime traffic services which includes 51 state line and serviced by 14 shipping companies with 77 ships. Permanent and regular lines between the islands and mainland and between the islands is essential for sustainable development of the islands, but it must not ignore the negative impact of maritime traffic on the environment. Croatian's strategic goal is safe and environmentally sustainable maritime traffic and space which includes an active change in the system of the the coastal maritime traffic. A prerequisite change is to raise awareness about the environment and causes of pollution.
\end{abstract}

\section{ARTICLE INFO}

Review article

Received 5 May 2019

Accepted 28 May 2019

Key words:

Coastal maritime traffic

Environment

Alternative fuels

Electric ships

Reducing pollution

Attitudes

\section{Introduction}

The Croatian coast has 1246 islands, islets and cliffs [1] and it is one of the most indented coast in Europe and worldwide. According to the last census in 2011, 2.92\% of the total Croatian population living on islands [2] and one of the most important factors for the island's population is the public traffic system in the context of the coastal maritime traffic because it ensures regular services between the islands and mainland and between the islands themselves. There would not be life and sustainable development of the inhabited islands without this. This system comprises 51 state's lines (24 ferry lines, 15 catamaran lines and 12 classic shipping lines) which maintenance 14 companies with 77 vessels [3]. The most prominent problems of the the coastal maritime traffic in Croatia are: unfavorable age structure of the fleet, a high share of fuel's prices in the total costs of traffication and significant seasonal fluctuations, but it should not be neglected either of the negative impact on the environment, especially in the segment of harmful gas emissions in the atmosphere. Maritime traffic causes large amounts of greenhouse gases and air pollutants, noise pollution and water pollution. It is expected that until 2050 carbon dioxide emissions from maritime traffic could reach $17 \%$ of all carbon dioxide emissions [4]. New solutions are urgently required to reduce these trends. The trend of increasing the use of renewable energy sources in all branches of the economy and life is already present in Europe, as evidenced by the example in Denmark where the energy from the wind approaches the current energy consumption [5]. Croatia is taking some measures to keep up with European and world trends in an effort to reduce dependence on oil and the increased use of alternative fuels, but it is necessary to invest in the necessary infrastructure. Dynamics of investment in the necessary infrastructure for using of alternative energy sources for traffic vehicles and vessels in line with the objectives defined in the National Center Policy Framework for Infrastructure Establishment and Development of Alternative Fuel Market (NOP), based on the Law on Establishment of Infrastructure for alternative fuels (NN, No. 120/2016). This Act is in accordance with the provisions of Directive 2014/94 / EC of the European 
Parliament and of the Council of 22 October 2014 on the establishment of infrastructure for alternative fuels in that part of the Member State concerned. Timely construction of the relevant infrastructure would ensure technological neutrality and the development of new markets and create preconditions for the realization of the basic goal, which is mitigating the negative impact of traffic on the environment. The Energy Development Strategy of the Republic of Croatia says that it is necessary to build new infrastructure facilities until 2030, such as those for electricity transfer, liquefied natural gas, compressed natural gas and, as appropriate, hydrogen, for vehicles or vessels [6].

In addition to this, it is important to raise awareness of this issue at all levels so that all participants actively work on the necessary changes.

This paper analyzes the data collected through a survey conducted to examine the views on the use of ships on electric power in the system of the coastal maritime traffic in the Republic of Croatia.

\section{The Survey about Introduction of Electric Ships in the Coastal Maritime Traffic in Croatia}

Maritime traffic is very important for Croatia, as evidenced by all legal acts and regulations that seek to improve maritime traffic and to improve the connection of the islands with the mainland and between the islands. Aim is sustainable development of the islands which includes the economic development and improving the demographic picture. The goverment gave 381,251,166.05 $\mathrm{kn}$ for maintaining state lines in the system of the the coastal maritime traffic in 2017 [7]. The system of the the coastal maritime traffic in Croatia serviced by 14 shipping companies with 77 ships. All 77 ships use diesel fuel which implies a negative effect on the environment due to greenhouse gas emissions. By raising awareness of the negative impacts of environmental traffic, a number of legal constraints are introduced at global level to minimize adverse factors. So the shipping companies are forced to look for new fuels and propulsion systems, although a realistic view of the situation suggests that Croatia will follow novelties regarding the use of alternative energy in shipping with a time lag because of the previously required great investment in infrastructuree. However, current trends as well as the observed needs indicate future changes in the the coastal maritime traffic in Croatia so a survey was conducted to examine the attitudes towards the introduction of electric ships. The survey included 80 people and all subjects were participants of the system.

Subjects were divided into 4 groups:

1. the island population,

2. chief engineer on ships in the system of the coastal maritime traffic in Croatia,

3. shipping companies

4. public-sector employees.

Selection of the sample was made due to the inclusion in the system of the coastal maritime traffic. The island's population actively uses this form of traffic while chief engineers, shipping companies and public sector employees are experientially and operationally connected to the system, so their attitudes are relevant in this case. The survey was conducted over a period of one month, and the data obtained through the survey were statistically processed through the SPSS program.

\section{Statistical Analysis of the Data}

The survey included 80 people which divided into 4 groups: the island population, the chief engineer on ships in the system of the the coastal maritime traffic in Croatia, shipping companies and employees of the public sector. The reason for this kind of segmentation is that these groups are closely correlated with the system of coastal liner shipping in terms of servicing the system or its use, and mutual dependence indicates a great deal of interest in the subject. Figure 1 shows the structure of the respondents, so it is evident that the largest number of respondents are in the category of islands population ( 25 out of 80 respondents), and the smallest number of respondents belong to the category of management or owners of shipping companies in the the coastal maritime traffic system of Croatia (15 out of 80).

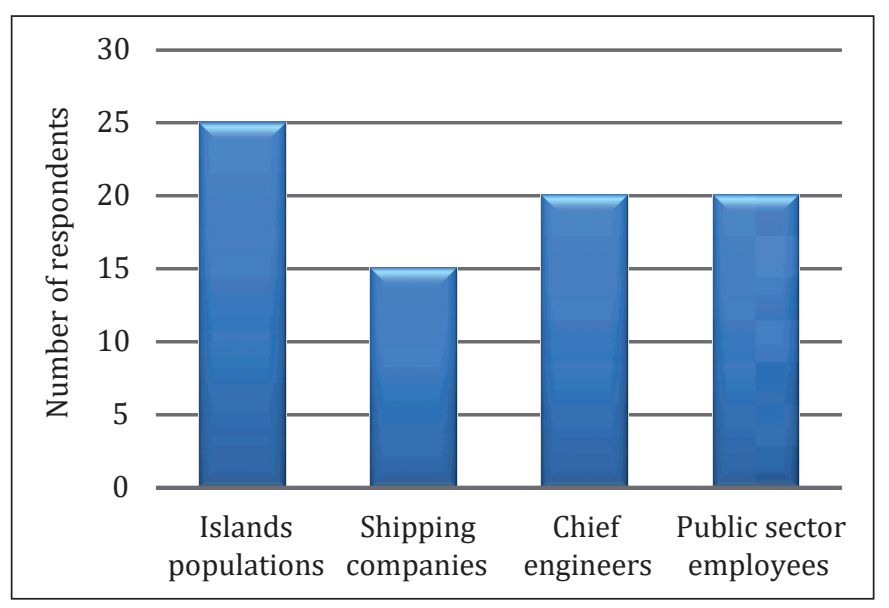

Figure 1 Structure of respondents Source: Authors

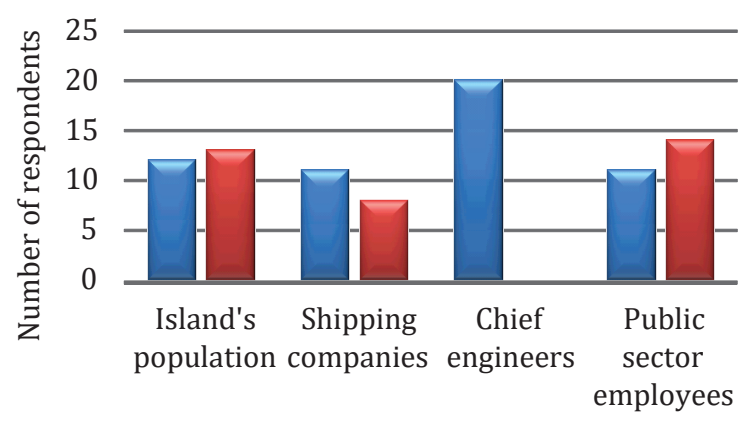

$\nabla \mathrm{M} \nabla \mathrm{F}$

Figure 2 Number of respondents by gender Source: Authors 
Analyzing Figure 2, it is concluded that there are more women in the group of the island population and in the public sector, while the menagers or owners of the shipping company are mostly men, but among chief engineers there are no women.

Through analysis of variance examines the difference between the mean values of certain variables within categories of respondents. The level of significance is set to 0.05 . Hypotheses:

H0: There is no statistically significant difference in the mean values of certain variables between categories of respondents.

H1: There is a statistically significant difference in the mean values of certain variables between categories of respondents.
Analyzing Table 1 it can be concluded that the p-value of all variables is less than 0.05 , so it rejects the null hypothesis that there is no statistically significant difference in mean values between categories of respondents for all variables (gender, age, qualification, employment status, place of residence). Therefore, it is concluded that there is a statistically significant difference between groups for all mentioned variables. Further, a post-hoc Tukey test analyzes statistically significant differences between the groups which confirms previous results obtained or collected in the ANOVA. This test is examined where the significance is less than 0.05 , because it concludes between which categories are significant differences in the mean values for each variable. Table 2 shows the results for the variable sex where is $p$-value

Table 1 Processing basic characteristics of respondents by ANOVA

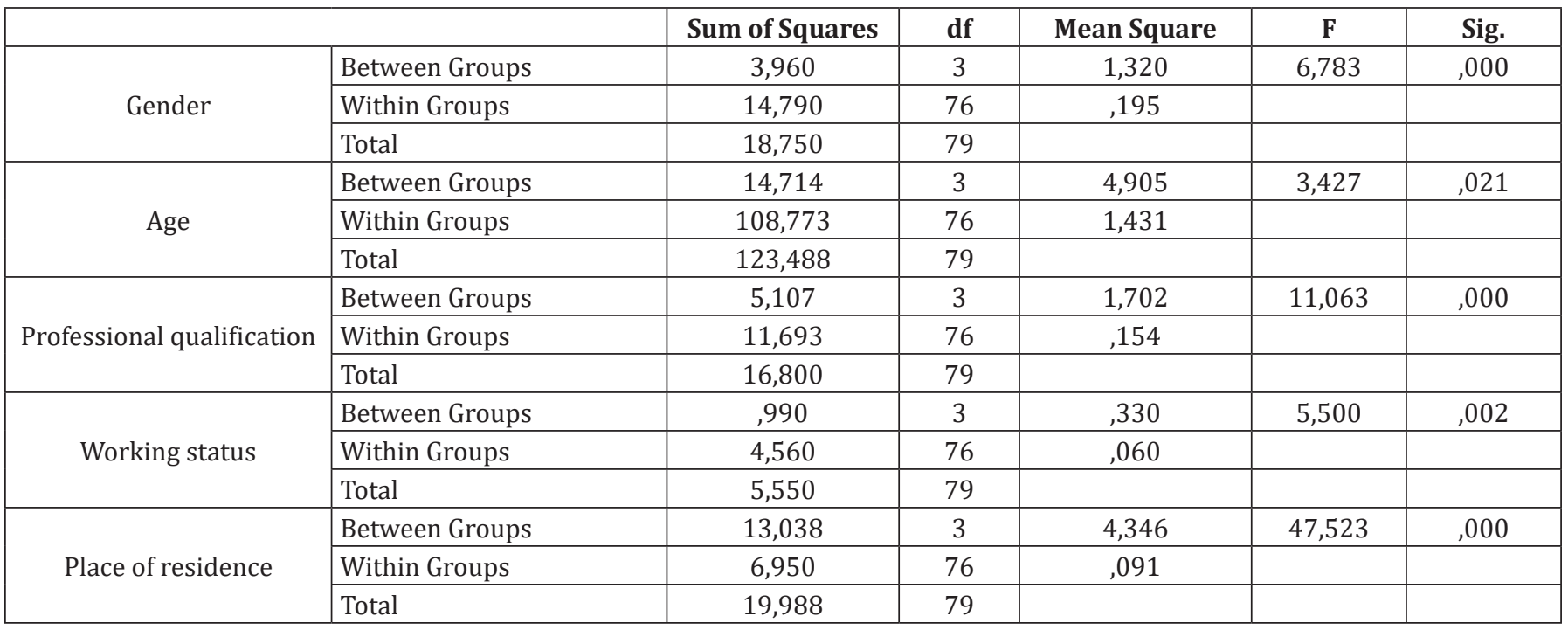

Source: Authors

Table 2 Multiple comparison (Tukey HSD)

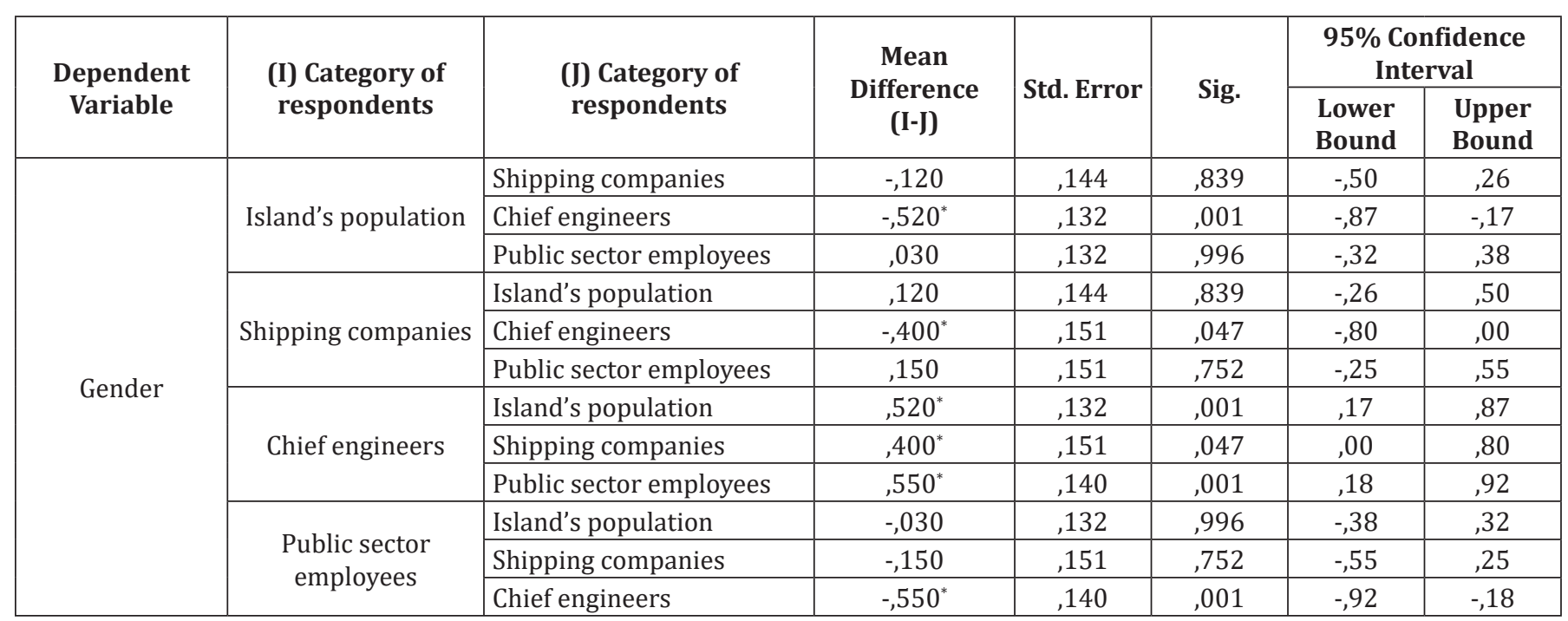

* The mean difference is significant at the 0.05 level. 


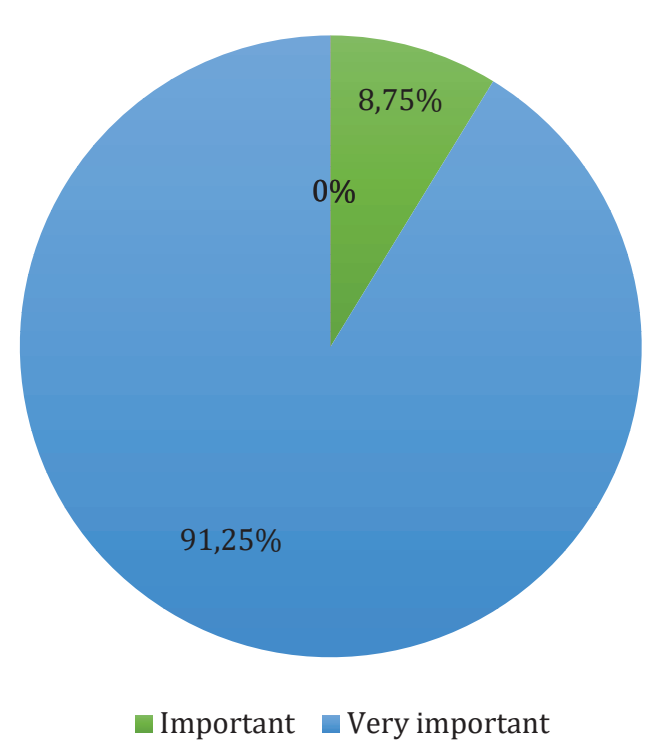

Figure 3 Importance of connecting the island with the mainland Source: Authors

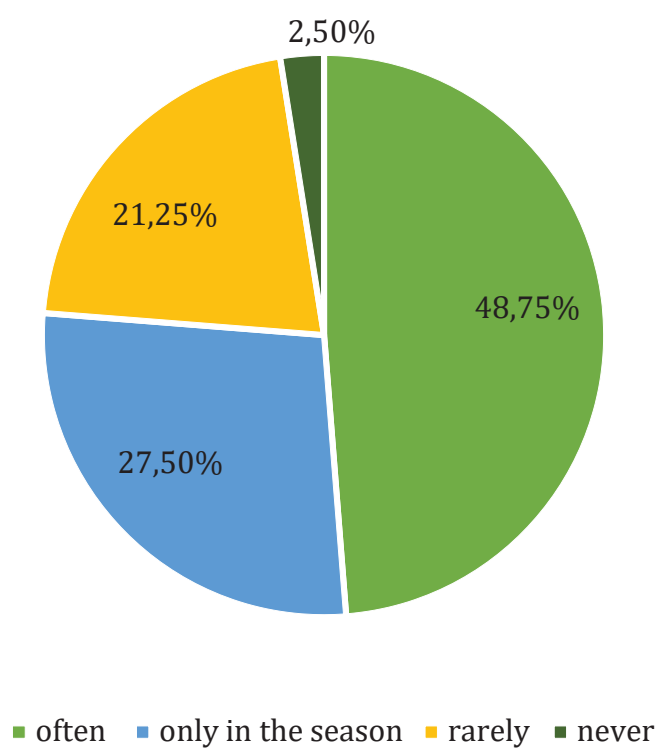

Figure 5 Frequencies of using public maritime traffic Source: Authors

between group islanders and group chef engineers is 0.001 , which means that between these two categories is a significant difference in the number of men and women which is confirmed Figure 1, because the chief engineers only men and the islanders have approximately the same number of men and women.

Analyzing Graphs on Figures 3-6 it is concluded that even $91.25 \%$ of respondents consider the connection between the islands and the mainland is as important category, although only $53.75 \%$ of respondents are satis-

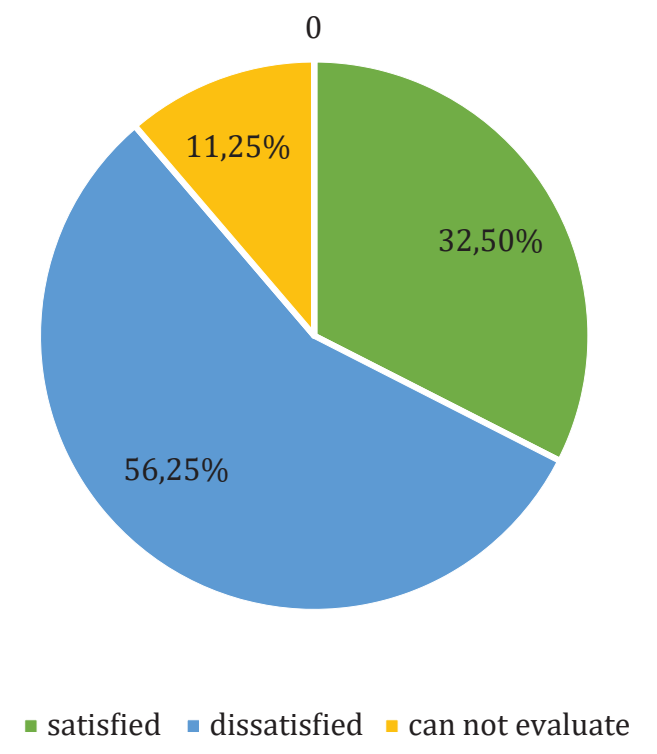

Figure 4 Satisfaction with the existing fleet of the system Source: Authors

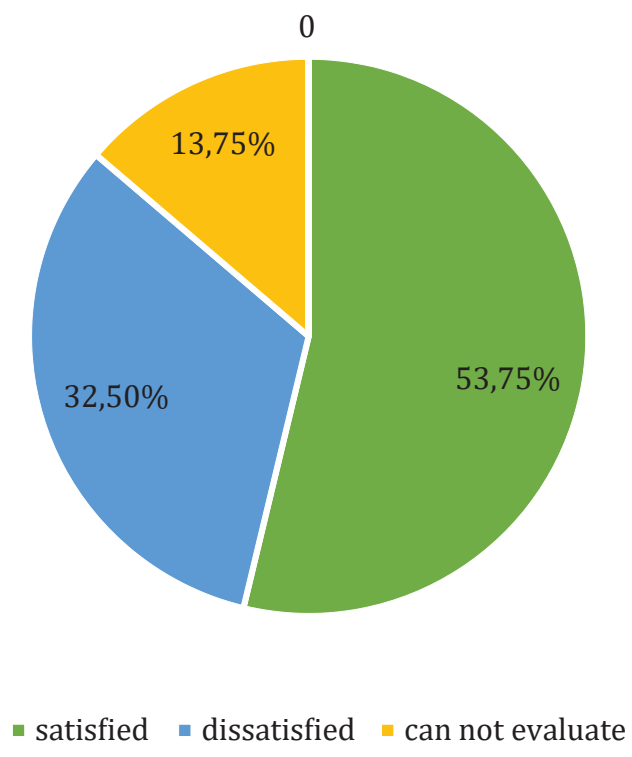

Figure 6 Satisfaction with the system of coastal maritime traffic Source: Authors

fied with the existing system and $56.25 \%$ are dissatisfied with the existing fleet. Public shipping is not only used by $2.50 \%$ of respondents.

Table 3 shows the value of 0.396 Spearman coefficient which would mean that there is a weak link (moderate with coefficient 0.4 ) between the answers to these two questions. The p-value is extremely small, so it can be conclude that this correlation is statistically significant at a significance level of 0.05 (and even at a significance level of 0.01). 
Table 3 Correlations of previous questions

\begin{tabular}{|c|c|c|c|c|}
\hline \multicolumn{5}{|c|}{ Correlations } \\
\hline & & & $\begin{array}{c}\text { How would you rate your } \\
\text { satisfaction with the existing } \\
\text { coastal maritime traffic system? }\end{array}$ & $\begin{array}{c}\text { How would you rate your satisfaction } \\
\text { with the existing fleet in coastal maritime } \\
\text { traffic of the Republic of Croatia? }\end{array}$ \\
\hline \multirow{4}{*}{ 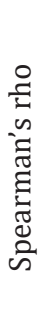 } & \multirow{2}{*}{$\begin{array}{l}\text { How would you rate your } \\
\text { satisfaction with the existing } \\
\text { coastal maritime traffic } \\
\text { system? }\end{array}$} & $\begin{array}{c}\text { Correlation } \\
\text { coefficient }\end{array}$ & 1,000 & ,396* \\
\hline & & Sig. (2-tailed) & . & ,000 \\
\hline & \multirow{2}{*}{$\begin{array}{l}\text { How would you rate your } \\
\text { satisfaction with the existing } \\
\text { fleet in coastal maritime traffic } \\
\text { of the Republic of Croatia? }\end{array}$} & Sig. (2-tailed) & , 000 & . \\
\hline & & $\mathrm{N}$ & 80 & 80 \\
\hline
\end{tabular}

**. Correlation is significant at the 0.01 level (2-tailed).

Source: Authors

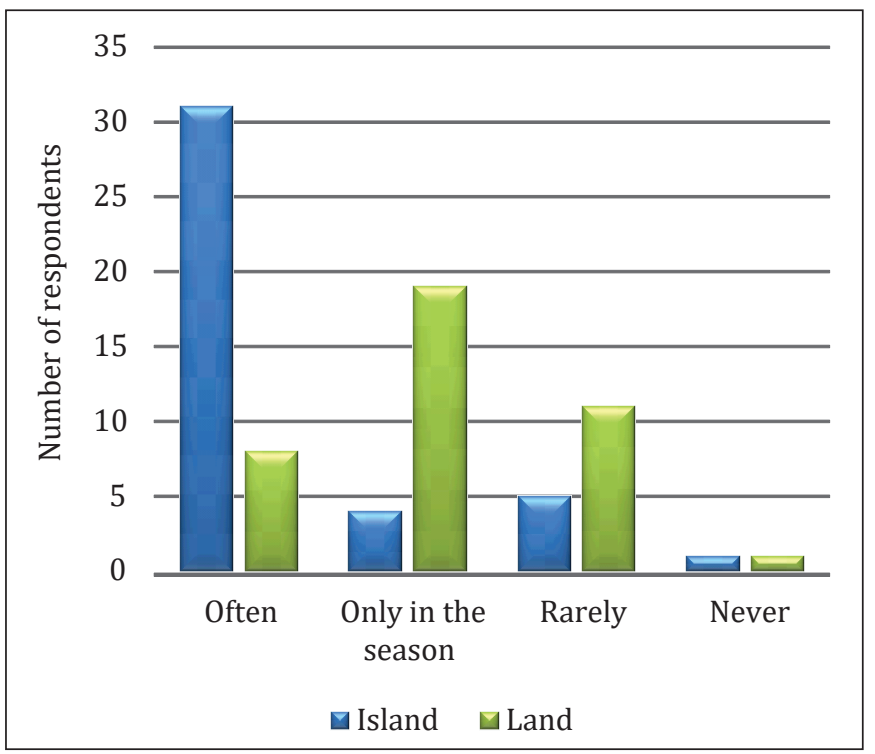

Figure 7 shows that respondents who live on the island often use public ship's traffic, while those who living on land use it in the period of the season (1.6.-30.9.) or rarely.

Furthermore, it is concluded from Figure 8 that respondents who often or only during the season use public maritime traffic are most dissatisfied with the naval fleet of the Republic of Croatia.

Figure 9 and Table 4 show that the majority of respondents believe that the the coastal maritime traffic causes pollution in the Republic of Croatia so it should switch to the use the electric ships, because of environmental reasons, but also because of the image of the Republic of Croatia. They also think that it should be financed by the state and (mostly) without increasing the price of traffic tickets.

Figure 7 Frequencies of using public maritime traffic by place of residence Source: Authors

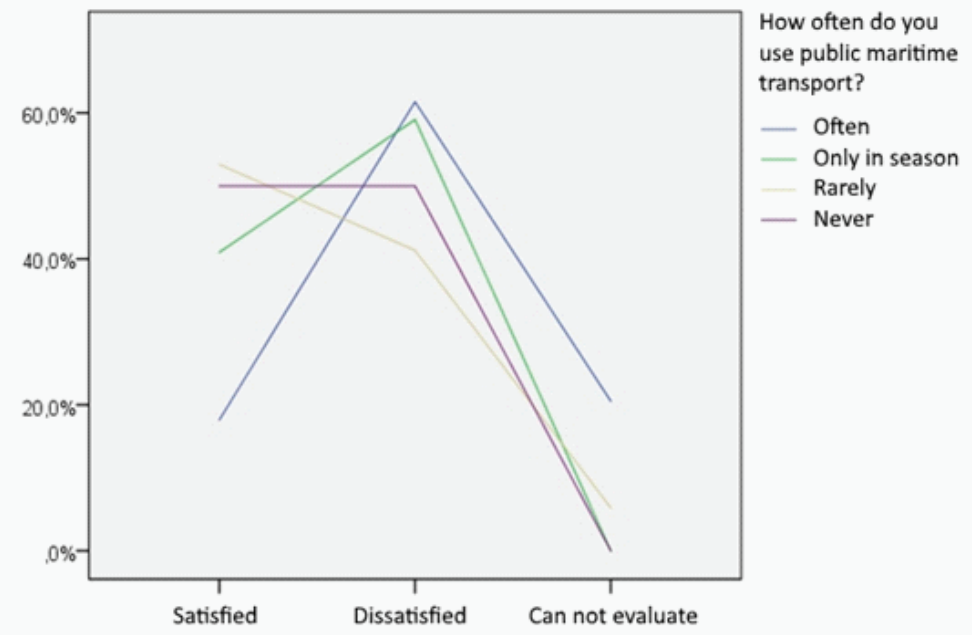

How would you rate your satisfaction with the existing fleet in coastal maritime traffic of the Republic of Croatia? 


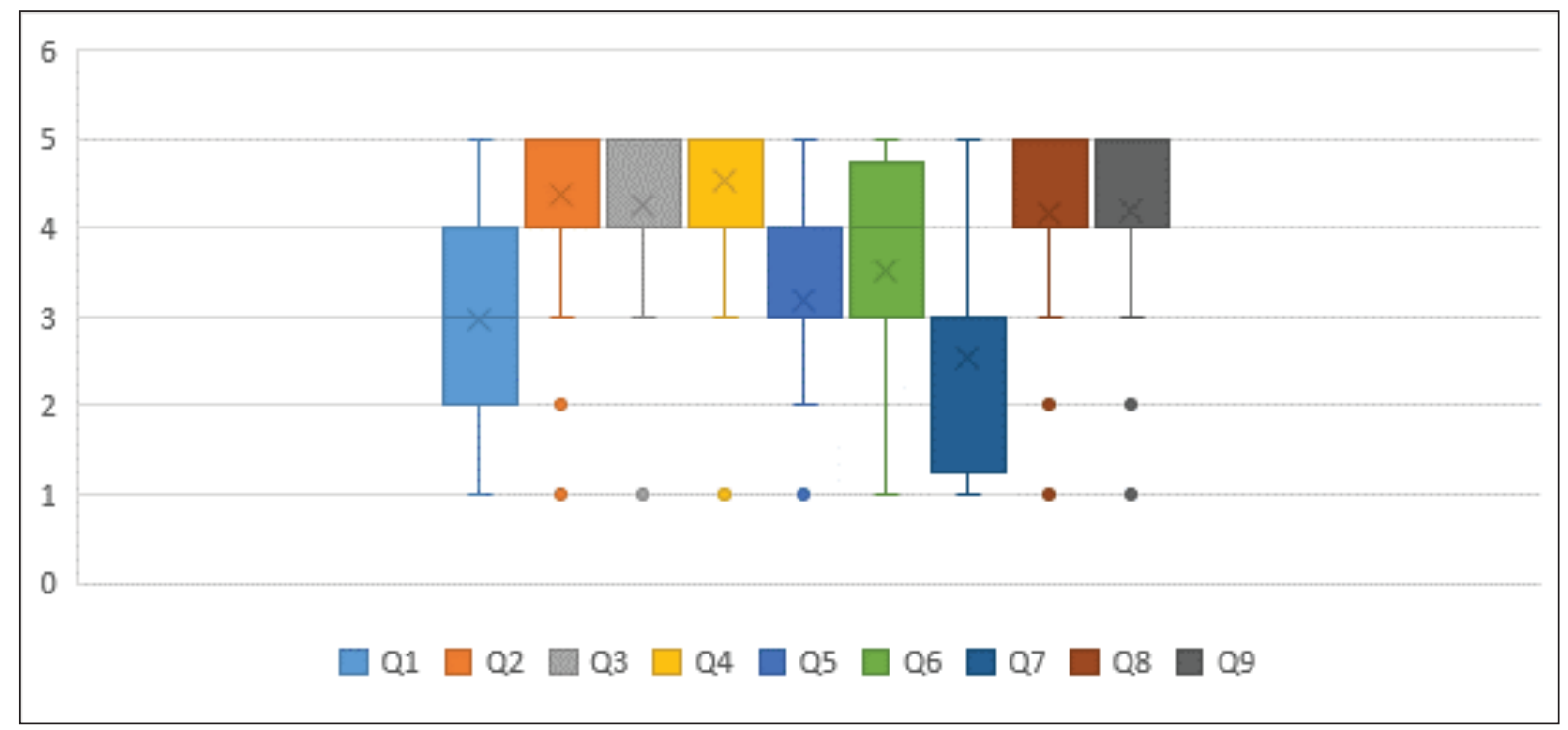

Figure 9 Boxplot for attitude of respondents on coastal maritime traffic and reduction of environmental pollution Source: Authors

Table 4 Attitude of respondents on coastal maritime traffic and reduction of environmental pollution

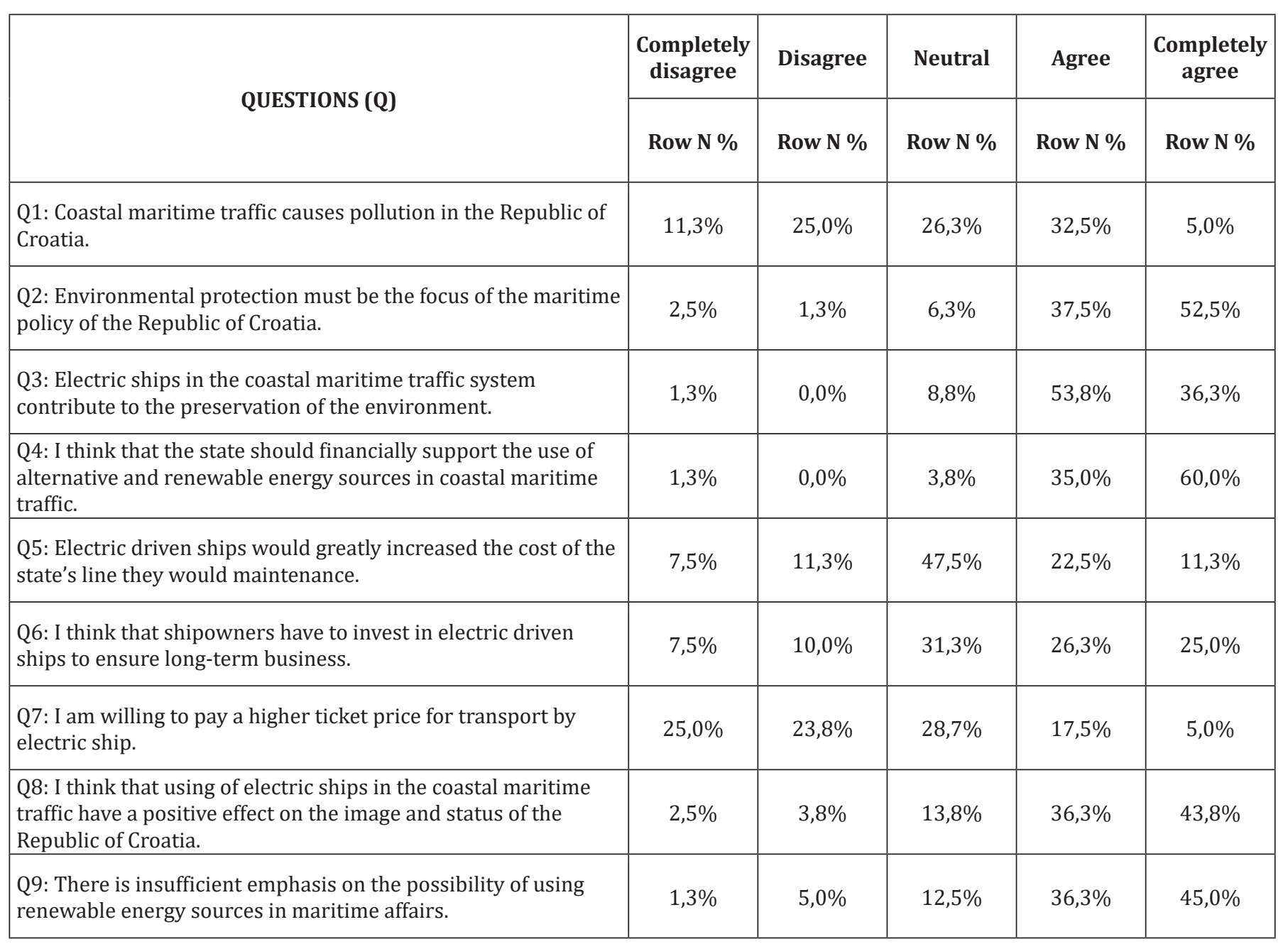


Table 5 Correlations of previous questions

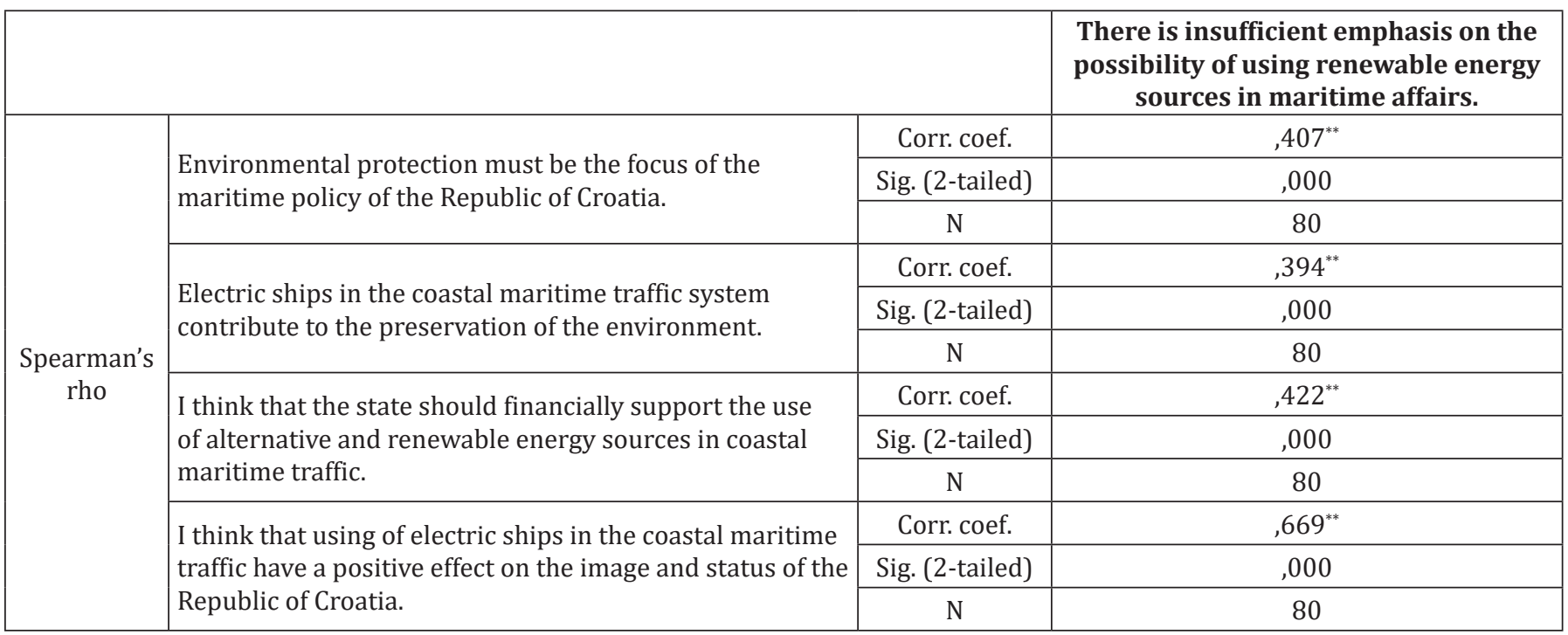

Source: Authors

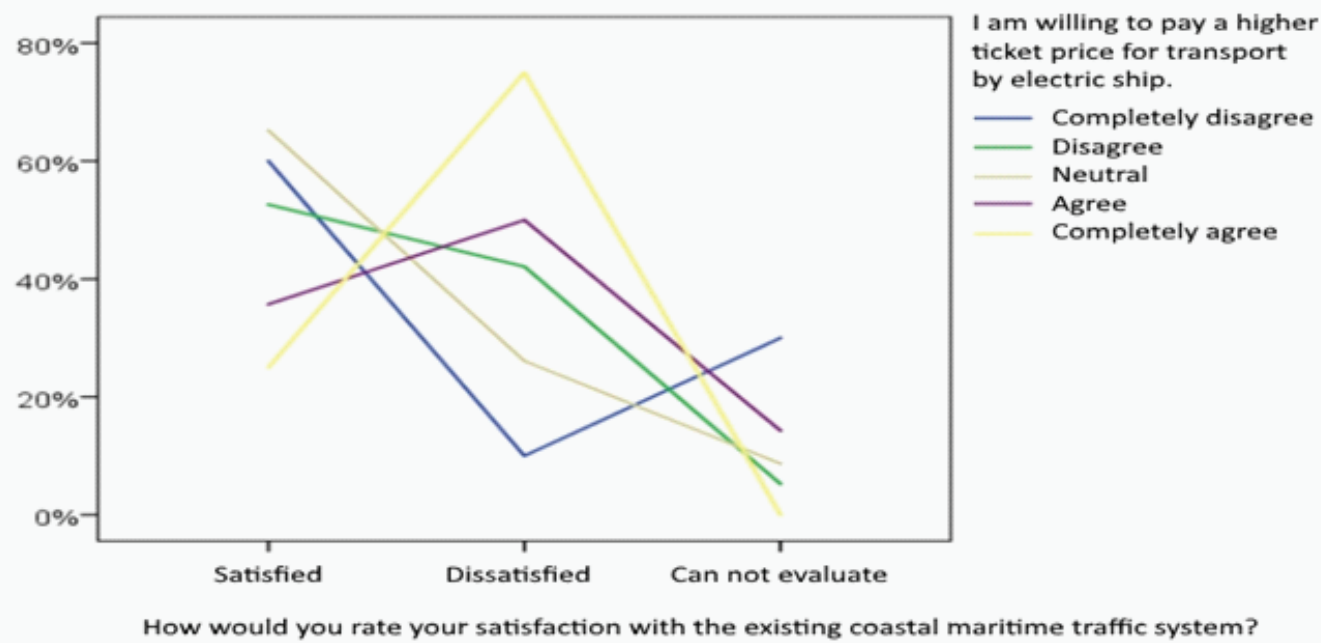

Figure 10 Relation between the system and ticket price of transport Source: Authors

The question of insufficient emphasis on the possibility of using renewable energy sources in maritime moderately or strongly positively correlated with all other questions from the table at a significance level of 0.01 . Respondents, who agree that such opportunities are not highlighted, agree with the findings in other issues. Respondents, who do not agree that such opportunities are not highlighted, do not agree either with other findings. This is evident in the Table 5 .

And finally, Figure 10 shows a significant fact that most respondents who are (fully) agree that they are willing to pay a higher price of traffic ticket for electric ships are dissatisfied with the existing system of maritime traffic, while those who are not willing to pay a higher price are satisfied with the existing system.

\section{Conclusion}

Traffic has a major impact on the development of society and the economy, but the traffic also has a negative impacts on the environment and quality of life. All traffic branches, including shipping, cause air, water and soil pollution, noise and vibration, visual degradation of space and distort the natural balance of flora and fauna. There are increasingly present various alternative solutions by raising awareness about the environment and pollution to limit the negative impact of maritime transport on the environment and reduce dependence on oil. Croatia is a maritime country characterized by highly indented coastline with 1,246 islands, islets and cliffs. The main goal is to improve the demographic situation and the sustainable development of the islands, 
and the public maritime trafficin is paramount important for the islands and the island's population. The system comprises 51 state lines maintained by 14 shipping companies with 77 ships. Following the European and global trends in environmental protection, it has to be some changes in this system, especially in order to finding alternative fuels with lower emissions. According this, 80 direct participants in the coastal maritime traffic were interviewed to examine their views on the introduction of electric ships. Rispondents are: the island's population, chief engineers, shipping companies and public sector employees. Analyzing data obtained by conducting the present survey concludes that the selected sample is relevant because all respondents used this form of public transport. The largest number of respondents are the island's population, which largely depend on this system, so their attitudes are the most authoritative. The survey found that coastal maritime traffic is very important, but users are not satisfied with the system and the existing fleet, which confirms the needs for active changes and increasing quality. Most respondents believe that it is necessary to take certain measures to protect the environment and support the introduction of elecric driven ships, but they do not want to accept increasing price of transport tickets. They believe that the state should financially support the increase costs in transport caused by using the alternative fuels. Most respondents believe that such a measure would reduce the negative impact on the environment, and improve the image and status of the Republic of Croatia.

\section{References}

[1] Duplančić-Leder, T., Ujević, M. i Viđak, I., 2000, 'Categorization and number of islands in the Republic of Croatia', Periodicum Biologorum, vol.102, Suppl 1, p. 281-284.

[2] Lajić, I., Mišetić, R., 2013, Demographic Changes on Croatian Islands at the Beginning of the 21st Century, Migration and Ethnic Themes, vol. 29, no. 2, p. 169-199.

[3] Agency for Coastal Lines and Maritime Traffic, http://www. agencija-zolpp.hr/, (accessed 01 April 2019)

[4] European Environment Agency, Aviation and shipping emissions in focus, https://www.eea.europa.eu/articles/ aviation-and-shipping-emissions-in-focus, ( accessed 12 April 2019)

[5] Karsalihović-Sedlar, D., Jukić, L., 2017, Utjecaj Strategije niskougljičnog razvoja Republike Hrvatske na energetski sektor nafte i plina, Nafta i plin, vol.37, no2 152, p.36-46.

[6] Analysis and the base for developing the Energy Strategy of the Republic of Croatian, Reply to comments on the draft Green Paper published 30 October 2018, 2019, Energetski institut Hrvoje Požar, Zagreb, https://www.mzoip.hr/doc/ zelena_knjiga_odgovori_na_zaprimljene_komentare_na_ nacrt_zelene_knjige.pdf, (accessed 12 April 2019.)

[7] Report of Implementation of the Islands Act 2017, https:// sabor.hr/hr/izvjesce-o-ucincima-provedbe-zakona-o-otocima-u-2017-godini-podnositeljica-vlada-republike-hrvatske, (accessed 02 April 2019.) 